\title{
Capillary based Li-air batteries for in situ synchrotron X-ray powder diffraction studies
}

\author{
Storm, Mie Møller; Johnsen, Rune E.; Younesi, Reza; Norby, Poul
}

Published in:

Journal of Materials Chemistry A

Link to article, DOI:

$10.1039 / \mathrm{c} 4 \mathrm{ta0} 4291 \mathrm{c}$

Publication date:

2015

Document Version

Peer reviewed version

Link back to DTU Orbit

Citation (APA):

Storm, M. M., Johnsen, R. E., Younesi, R., \& Norby, P. (2015). Capillary based Li-air batteries for in situ synchrotron X-ray powder diffraction studies. Journal of Materials Chemistry A, 3(6), 3113-3119.

https://doi.org/10.1039/c4ta04291c

\section{General rights}

Copyright and moral rights for the publications made accessible in the public portal are retained by the authors and/or other copyright owners and it is a condition of accessing publications that users recognise and abide by the legal requirements associated with these rights.

- Users may download and print one copy of any publication from the public portal for the purpose of private study or research.

- You may not further distribute the material or use it for any profit-making activity or commercial gain

- You may freely distribute the URL identifying the publication in the public portal

If you believe that this document breaches copyright please contact us providing details, and we will remove access to the work immediately and investigate your claim. 


\title{
Capillary based Li-air batteries for in situ synchrotron X-ray powder diffraction studies
}

\author{
Mie Møller Storm, Rune E. Johnsen, Reza Younesi and Poul Norby \\ Department of Energy Conversion and Storage, Technical University of Denmark, Frederiksborgvej \\ 399, DK-4000 Roskilde, Denmark
}

\begin{abstract}
For Li-air batteries to reach their full potential as energy storage system, a complete understanding of the conditions and reactions in the battery during operation is needed. To follow the reactions in situ a capillary-based $\mathrm{Li}-\mathrm{O}_{2}$ battery has been developed for synchrotron-based in situ X-ray powder diffraction (XRPD). In this article, we present the results for the analysis of $1^{\text {st }}$ and $2^{\text {nd }}$ deep discharge and charge for a cathode being cycled between 2 and $4.6 \mathrm{~V}$. The crystalline precipitation of $\mathrm{Li}_{2} \mathrm{O}_{2}$ only is observed in the capillary battery. However, there are indications of side reactions. $\mathrm{The}^{\mathrm{Li}} \mathrm{O}_{2} \mathrm{O}_{2}$ diffraction peaks grow with the same rate during charge and the development of the full width at half maximum (FWHM) is $h k l$ dependent. The difference in the FWHM of the 100 and the 102 reflections indicate anisotropic morphology of the $\mathrm{Li}_{2} \mathrm{O}_{2}$ crystallites or defects along the $c$-axis. The effect of constant exposure of X-ray radiation to the electrolyte and cathode during charge of the battery was also investigated. X-ray exposure during charge leads to changes in the development of the intensity and the FWHM of the $\mathrm{Li}_{2} \mathrm{O}_{2}$ diffraction peaks. The X-ray diffraction results are supported by ex situ Xray photoelectron spectroscopy (XPS) of discharged cathodes to illuminate non-crystalline deposited materials.
\end{abstract}

\section{Introduction}

Li-air $\left(\mathrm{Li}-\mathrm{O}_{2}\right)$ batteries have a theoretical specific energy density comparable to the efficient gravimetric energy density of gasoline, which make them an ideal energy source for battery driven electric vehicles ${ }^{1}$. In the Li-air battery, Li-ions react with oxygen from the air causing precipitation of $\mathrm{Li}_{2} \mathrm{O}_{2}$ on the air-cathode. The air-cathode is often carbon-based as carbon gives the opportunity to have a light-weight, conducting, and porous cathode. Cathodes based on reduced graphene oxide have demonstrated Li-air batteries with very high capacities ${ }^{2-4}$. However, many challenges are still unsolved for the Li-air battery. Different side reactions take place in the battery and the electrolyte as well as the 
cathode have been found to decompose in the oxidizing environment ${ }^{5-9}$. The Li-air battery furthermore has a high overpotential and challenges in regards to cyclability ${ }^{1}$. Several studies show the possibility for a future development of the Li-air battery: Shui et al. ${ }^{10}$ demonstrated a capacity limited battery cycled 150 times and theoretical studies shows the possibility of lowering the overpotential for the reversible precipitation of $\mathrm{Li}_{2} \mathrm{O}_{2}{ }^{11}$. The many challenges may be overcome if a clear picture of the conditions and reactions in the battery during operation is obtained. In situ studies provide an opportunity to explore systems with a minimum of external interference. Investigation of the cathode and anode materials during discharge and charge is of importance, as these components may hold the key to making a rechargeable Li-air battery with high capacity.

Different designs for in situ X-ray diffraction (XRD) studies of Li-air batteries have been explored; Lim et al. ${ }^{12}$ designed a battery setup with Li metal on a stage and a cathode separated by a glass fiber separator assembled within a flow chamber with X-ray transparent windows. Ryan et al. ${ }^{13}$ performed in situ XRD on a $\mathrm{Li}_{2} \mathrm{O}_{2}$ coin cell. The coin cell was set up with Kapton windows within a Kapton sealed flow box. A cell-design based on a Swagelok cell was developed by Shui et al. ${ }^{14}$ who investigated the capacity limited discharge/charge on a cell containing Li metal, glass micro-fiber filter, and cathode encapsulated in tubular glass.

Capillary-based batteries for in situ X-ray powder diffraction (XRPD) analysis have been used for investigation of Li-ion batteries ${ }^{15}$, but no Li-air capillary batteries have yet been designed. We have developed a Li-O $\mathrm{O}_{2}$ capillary battery consisting of an electrolyte filled capillary with anode and cathode in each end coated on stainless steel wires. The oxygen in-let is placed on the cathode-side with a flushing system placed above the capillary. In this study, we present a flexible design of a capillary Li$\mathrm{O}_{2}$ battery with discharge and charge investigated using synchrotron-based XRPD. Pure oxygen gas was used as even small amount of impurities as for example $\mathrm{CO}_{2}$ affects the battery performance ${ }^{16}$. The capillary batteries are therefore termed $\mathrm{Li}-\mathrm{O}_{2}$ batteries in this paper.

In situ XRPD during $1^{\text {st }}$ and $2^{\text {nd }}$ discharge/charge (between 2- $4.6 \mathrm{~V}$ ) of different battery cells were performed. The effect of X-ray exposure during charging of $\mathrm{Li}^{-} \mathrm{O}_{2}$ batteries was investigated and cathodes deep discharged 1 and 2 times were analyzed ex situ with X-ray photoelectron spectroscopy (XPS) to obtain a complete view of the reactions taking place at the air electrode. 


\section{Results and Discussion:}

This section will start with an introduction to the capillary battery set up and general abilities of the capillary batteries. This is followed by a presentation of the in situ XRPD tested batteries (battery 1, 2 and 3), and the XRPD results obtained. The in situ results will be followed by a presentation of the $e x$ situ XPS analysis of the deeply discharged carbon cathodes.

Figure 1 shows the $\mathrm{Li}-\mathrm{O}_{2}$ capillary cell design, (a picture of the actual $\mathrm{Li}^{-} \mathrm{O}_{2}$ capillary battery is shown in Figure S1). The cathode is mounted on a stainless steel (SS) wire in a quartz tube opposite a Li-anode likewise on a SS wire. Quartz tubes were used for XRPD in situ measurements and boro silicate capillaries were used for battery tests without X-ray analysis. Both the cathode and the anode were completely covered by electrolyte and the oxygen was flushed through the flushing unit (Swagelok fitting, drawn in black) to fill the battery with gas. OCV was being measured for 2-3 h before the batteries was cycled between 2-4.6 V.

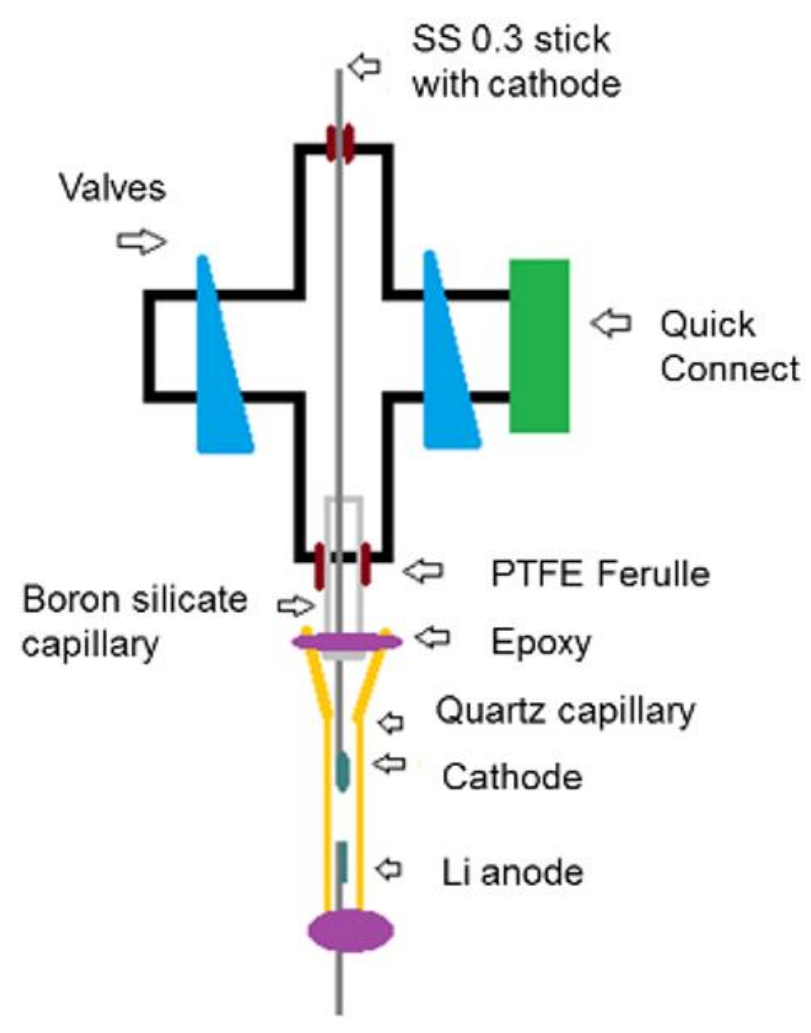

Figure 1: A schematic drawing of $\mathrm{Li}_{-} \mathrm{O}_{2}$ capillary battery for in situ XRPD analysis 
The ex situ batteries had the first discharge plateau around 2.5-2.6 V and a second flat discharge plateau at slightly higher voltage, around 2.7-2.8 V, see Figure 2 . The capillary batteries could be cycled between 2 and $4.6 \mathrm{~V}$ up to 7 cycles and still maintain a significant capacity, approximately up to $80 \%$ of initial discharge capacity.

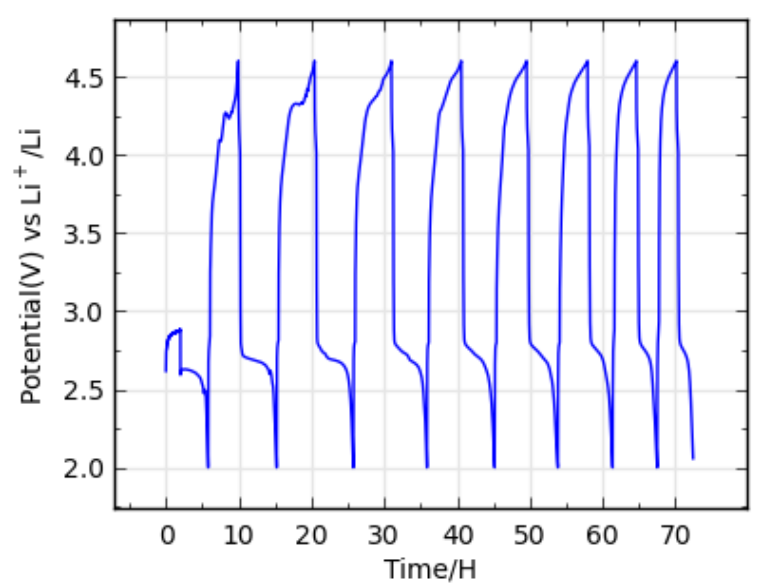

Figure 2: Cycling curves of a $\mathrm{Li}_{-} \mathrm{O}_{2}$ capillary battery upon deep cycling test.

An ex situ XRPD measurement of a discharged cathode showed the presence of $\mathrm{Li}_{2} \mathrm{O}_{2}$ and confirmed the operation of the $\mathrm{Li}_{-} \mathrm{O}_{2}$ battery. Several other studies have shown that deeply discharged $\mathrm{Li}$-air batteries loose capacity upon cycling and that the electrolyte and/or carbon cathode decomposes to different carbonate species ${ }^{17,18}$. This was confirmed by ex situ XRPD measurements of a 5 times discharged cathode which revealed no $\mathrm{Li}_{2} \mathrm{O}_{2}$ but only other crystalline materials, among those $\mathrm{Li}_{2} \mathrm{CO}_{3}$, see Figure S2.

Battery 1 was discharged and charged, as shown in Figure 3, at different current rates with XRPD measurements performed every $10 \mathrm{~min}$ (30 seconds exposure). The discharge and charge curves were noisy and many spikes were observed under the test run, probably due to insufficient connections between the battery and the potentiostat. 


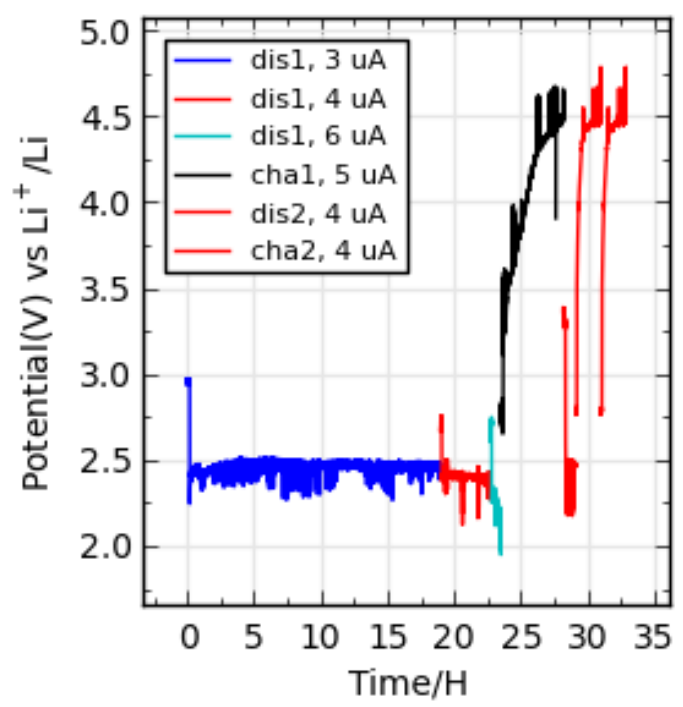

Figure 3: Discharge-charge curve of $\mathrm{Li}_{-} \mathrm{O}_{2}$ capillary battery number 1 for in situ analysis.

Figure 3 also show a small second discharge plateau for battery 1. No changes were observed in the intensity or the FWHM of the diffraction peaks during this second discharge and it is not included in the analysis of battery 1 . Battery 2 was discharged without exposure to X-ray, and charged with XRPD measurements performed every $10 \mathrm{~min}$, followed by charge with constant exposure to X-ray. Battery 3 was discharged and charged without $\mathrm{X}$-ray radiation, which was followed by analysis of the $2^{\text {nd }}$ discharge/charge cycle with X-ray exposure every $10 \mathrm{~min}$. An overview of the test condition for the batteries is presented in Table 1, further description is given in the experimental section.

Table 1: An overview of the tested batteries

\begin{tabular}{|l|l|l|}
\hline Name & In situ battery test & $\begin{array}{l}\text { Pretreatment } \\
\text { without X-ray }\end{array}$ \\
\hline Battery 1 & $\begin{array}{l}\text { Discharge, charge 1, discharge } \\
\text { (negligible) and charge 2 }\end{array}$ & $\begin{array}{l}\text { Equilibrated at } \\
\text { OCV }\end{array}$ \\
\hline Battery 2 & $\begin{array}{l}\text { Charged with 10 min X-ray exposure } \\
\text { every 10 min followed by charging at } \\
\text { constant X-ray exposure }\end{array}$ & $\begin{array}{l}\text { Equilibrated at } \\
\text { OCV and } \\
\text { Discharged }\end{array}$ \\
\hline Battery 3 & $2^{\text {nd }}$ discharge and charge & Equilibrated at \\
\hline
\end{tabular}




\begin{tabular}{|l|l|l|}
\hline & $\begin{array}{l}\text { OCV, discharged } \\
\text { and charged }\end{array}$ \\
\hline
\end{tabular}

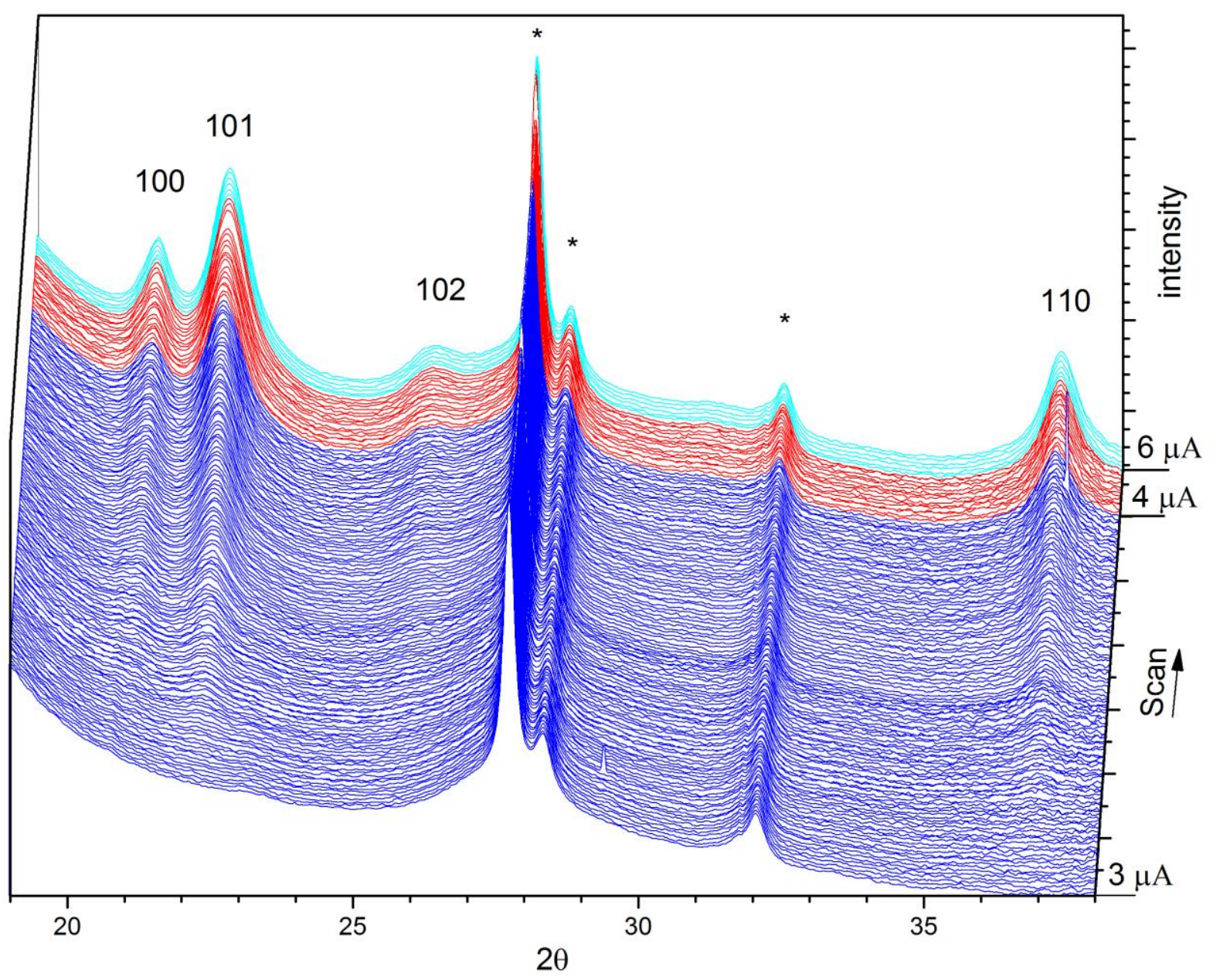

Figure 4: In situ diffraction patterns for the discharge of battery 1 showing the appearance of four diffraction peaks of $\mathrm{Li}_{2} \mathrm{O}_{2}$ and the ones of the SS wire (*). Blue represent a discharge current of $-3 \mu \mathrm{A}$, red $=-4 \mu \mathrm{A}$ and light blue $=-6 \mu \mathrm{A}$.

The in situ XRPD patterns collected during the discharge of battery 1 are displayed in Figure 4. Capillary battery 1 was discharged for a total of approximately $76 \mu \mathrm{Ah}$ and charged for $32 \mu \mathrm{Ah}$. Four different $\mathrm{Li}_{2} \mathrm{O}_{2}$ peaks were observed, the $100,101,102$, and $110\left(21.1^{\circ}, 22.4^{\circ}, 26.0^{\circ}\right.$, and $\left.37.0^{\circ}\right)$ 
reflections. The diffraction peaks at $27.8^{\circ}, 28.4^{\circ}$, and $32.1^{\circ}$ were caused by the steel wire. Figure 5 shows the area (integrated intensity) of $\mathrm{Li}_{2} \mathrm{O}_{2} 100$ diffraction peak vs. capacity. The curve appears linear, as seen in Figure 5 for the 100 diffraction peak (the data for the other diffraction peaks can be seen in Figure S3) which could indicate that no side reactions take place during the first discharge. When the areas of the diffraction peaks are normalized the slopes of the different diffractions are of similar values. However, extrapolation of the curves do not cross the origin (crosses $y=0$ at 0.013 (100), 0.002 (101), 0.012 (102), and $0.019 \mathrm{mAh}(110))$, and this indicates that some of the electrons in the battery take part in a different reaction than the $\mathrm{Li}_{2} \mathrm{O}_{2}$ formation.

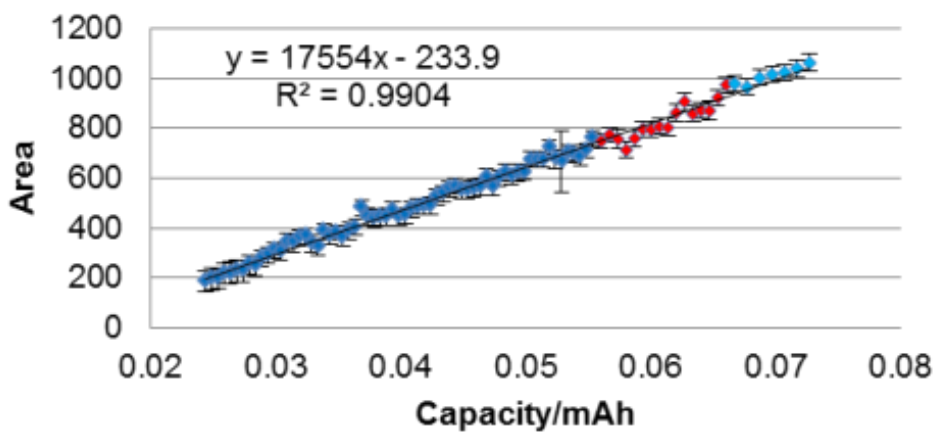

Figure 5: The development of the peak area of the 100 diffraction peak as a function of capacity. Dark blue equals a current of $-3 \mu \mathrm{A}$, red $=-4 \mu \mathrm{A}$ and light blue $=-6 \mu \mathrm{A}$.

The slope of the integrated area vs time (not shown here) of the 100,101 and $110 \mathrm{Li}_{2} \mathrm{O}_{2}$ diffraction peaks increased proportionally with increasing discharge rate as expected, as increased current leads to increased $\mathrm{Li}_{2} \mathrm{O}_{2}$ deposition, as can be seen from Figure 5 and $\mathrm{S} 3$ no change in the slope is observed in the area vs. capacity plot. The increase in discharge rate changed neither the battery voltage plateau nor the type of product being deposited. No other discharge products were observed during the test of battery 1 .

The charge of battery 1 revealed a decrease of intensity of the $\mathrm{Li}_{2} \mathrm{O}_{2}$ diffraction peaks for each of the separate charges. The results of area vs. capacity for the first charge are shown in Figure S4. The curves showed that the charge of the battery was slower than the discharge, as we for approximately a third of the charged capacity only observed a decrease in $\mathrm{Li}_{2} \mathrm{O}_{2}$ intensity of approximately $10-20 \%$. This could be caused by possible side reactions probably taking place at the high voltage. It was not 
possible to charge the battery completely since the connection in the battery was lost due to the formation of gas bubbles between the cathode and anode.

During discharge the FWHM of the growing 100 diffraction peak decreased, as did the FWHM of the 101 diffraction peak. The plots of the FWHM vs. capacity can be seen in Figure S5 for discharge and S6 for charge. The FWHM of the 102 and 110 diffraction peaks seem to be constant. However, the uncertainty of the parameters was higher as the intensity of these reflections was lower and the FWHM could only be determined in the last part of the discharge. The behavior of the FWHM during charging of battery 1 was more difficult to determine, but if one sees charge 1 and 2, as defined in Figure 3 , as a collected series, the FWHM of 100 diffraction peak increased upon charge as did the FWHM of 101 diffraction peaks. The FWHM development of the 100 and 101 diffraction peaks indicate crystallite growth in these directions upon discharge. The development of the FWHM of the 102 and 110 diffraction peaks was not conclusive.

The FWHM values of the 101 and 102 diffraction peaks were higher than those of the 100 and 110 diffraction peaks. This could indicate anisotropic morphology of the $\mathrm{Li}_{2} \mathrm{O}_{2}$ crystallites or defects along the $c$-axis.

Capillary battery 2 was discharged without exposure to X-ray for $5 \mathrm{~h} /-5 \mu \mathrm{A}$ yielding two different stages, the first being a plateau at the expected voltage for a $\mathrm{Li}_{-} \mathrm{O}_{2}$ battery with a voltage of $2.54 \mathrm{~V}$ and the second stage showing a decrease in voltage from 2.2-2.0 V, see Figure S7. The in situ charge was initiated by measurements every $10 \mathrm{~min}$ and later changed to being at constant X-ray exposure and scans of 30 seconds, see Figure 6. 


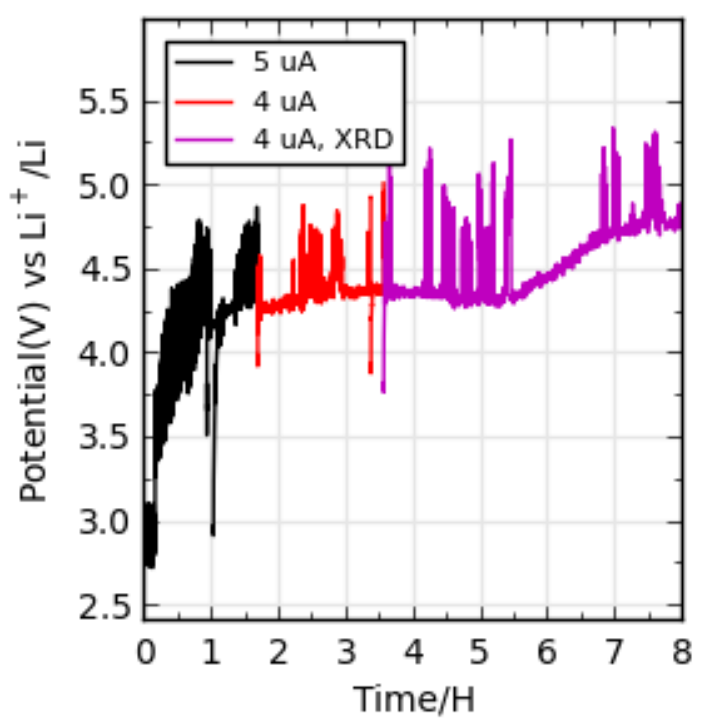

Figure 6: The charge curve of battery 2 under in situ XRPD measurements.

The battery reached a voltage plateau around 4.4 V during charge followed by a voltage increase, possibly caused by the depletion of precipitated material. Battery 2 was discharged for approximately $25 \mu \mathrm{Ah}$ and charged for approximately $23.5 \mu \mathrm{Ah}$ before the voltage increase. The results of the in situ measurements are shown in Figure 7, which shows both the 10 min measurements (black and red) and the results for the constant X-ray exposure (purple). 


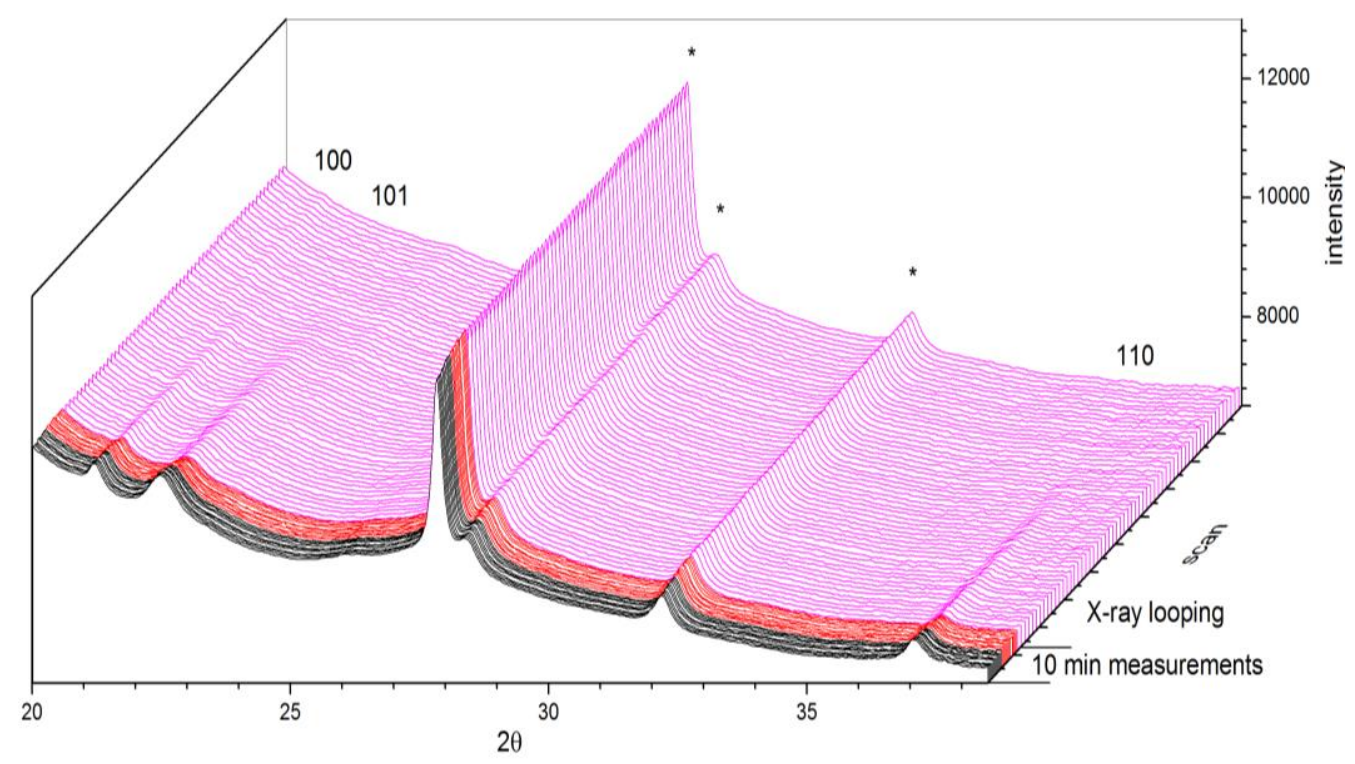

Figure 7: The in situ results for the charge of battery 2, showing the decomposition of the three $\mathrm{Li}_{2} \mathrm{O}_{2}$ diffraction peaks and the SS wire(*). Black = measurements performed every 10 minutes at $5 \mu \mathrm{A}$, red $=$ measurements performed every 10 minutes at $4 \mu \mathrm{A}$, purple $=$ continuous data collection during X-ray exposure at $4 \mu \mathrm{A}$. Only the first 80 constant exposure X-ray scans $(2.7 \mathrm{mAh})$ are displayed in the figure to make it visually easier to read, even though the decomposition of the peaks was observed for longer time.

The XRPD of battery 2 showed the presence of two additional unidentified diffraction peaks at 20.7 and $23.1^{\circ}$, beside the 100,101 and $110 \mathrm{Li}_{2} \mathrm{O}_{2}$ diffraction peaks. These small peaks were not observed in the other in situ batteries. Both peaks were very small and had almost constant intensity and FWHM during the charging both with and without constant X-ray exposure. With charging the intensity of all three $\mathrm{Li}_{2} \mathrm{O}_{2}$ diffraction peaks decreased.

During the 10 min measurements, the rate of the scan was changed from 5 to 4 a. The in situ XRPD measurements during constant X-ray exposure also showed a decomposition of $\mathrm{Li}_{2} \mathrm{O}_{2}$, see Figure $\mathrm{S} 8$. If we assume a linear decomposition of $\mathrm{Li}_{2} \mathrm{O}_{2}$, the decomposition rate increased by a factor of three for the 100 and 101 diffraction peaks when exposed to X-ray. The decomposition rate for the 110 diffraction peak increased only slightly with the constant X-ray exposure. However, care must be taken when making definite conclusion based on this data, since the 110 diffraction peak was of less intensity 
than the other reflection and thus more difficult to analyze. The 100 and 101 diffraction peaks indicate a large enhanced decomposition upon exposure to X-ray radiation.

The FWHM of the 100 diffraction peak increased with charge as did the FWHM of the 101 diffraction peak. This trend matches the one found for battery 1 . The FWHM of the 110 diffraction peak in battery 2 decreased with charge, see Figure S9. The broadening of the 100 and 101 increased drastically during the measurements made at constant X-ray exposure, see Figure 8 for the FWHM of the 101 diffraction peak vs. capacity, as did the sharpening for the 110 diffraction peak. This very steep increase only sligthly resembles that of the FWHM for the 100 and 101 diffraction peaks in battery 1 and it does not resemble the development of the 110 diffraction peak. This indicate that the constant X-ray exposure alters the FWHM development for all three diffraction peaks. Along with the drastic development of the area vs. capacity for the 100 and 101 difraction peak this display an effect of the constant X-ray exposure on the $\mathrm{Li}_{2} \mathrm{O}_{2}$. An accelerated electrochemical decomposition of $\mathrm{Li}_{2} \mathrm{O}_{2}$ by X-ray during charging was observed by Liu et al ${ }^{19}$ who detected decomposition of $\mathrm{Li}_{2} \mathrm{O}_{2}$ in a Li-air battery fabricated with a porous $\mathrm{Li}_{2} \mathrm{O}_{2}$ electrode in propylene carbonate electrolyte. The capillary battery results support the observation of increased $\mathrm{Li}_{2} \mathrm{O}_{2}$ decomposition by X-ray for reactions in dimethoxyethane (DME), and make it clear that the enhanced decomposition also is observed for $\mathrm{Li}_{2} \mathrm{O}_{2}$ which has been precipitated electrochemically during "normal” $\mathrm{Li}_{-} \mathrm{O}_{2}$ battery discharge.

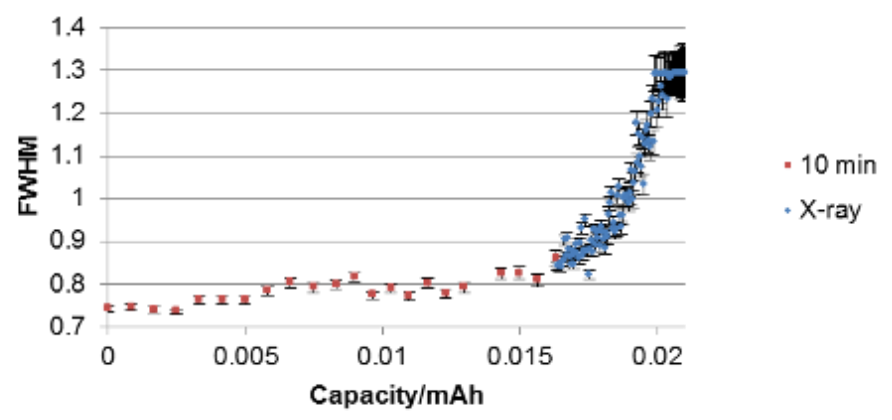

Figure 8: The development of the FWHM for the 101 diffraction peak during charge for battery 2 with and without constant X-ray exposure.

Battery 3 was studied in situ during the the $2^{\text {nd }}$ discharge/charge cycle, see Figure S10 for the discharge/charge plots of battery 3 . The diffraction peaks of this battery had much lower intensity 
compared to those of battery 1 and 2 . However, the apperence and disapperence of a small $101 \mathrm{Li}_{2} \mathrm{O}_{2}$ diffraction peak upon discharge was observed. No other diffraction peaks were observed for this battery. Whether the lack of intensity for the $\mathrm{Li}_{2} \mathrm{O}_{2}$ was due to the beam placement in the battery combined with the sligthly smaller slit size or the formation of less $\mathrm{Li}_{2} \mathrm{O}_{2}$ cannot be determined by diffraction alone, and ex situ XPS was performed on discharged cathodes. As the diffraction patterns are of low intensity no further analysis have been performed.

Ex situ XPS analysis was performed on cathodes deep discharged 1 or 2 times to investigate possible changes in the $\mathrm{Li}_{2} \mathrm{O}_{2}$ precipitation upon battery cycling. The $\mathrm{O} 1 \mathrm{~s}$ spectra of the discharged and stored cathodes, together with the peak assignments according to the references ${ }^{20-23}$, are displayed in Figure 9. The spectra indicate contributions from different oxygen-containing compounds such as $\mathrm{Li}_{2} \mathrm{O}_{2}$, carbonates, lithium bis(trifluoromethanesulfonyl)imide (LiTFSI) salt, and ethers/alkoxides at binding energies of 531.6, 532.3, 533, and $533.8 \mathrm{eV}$, respectively (there is also a small peak at very high binding at about $534.7 \mathrm{eV}$ suggesting $\mathrm{O}$ bonded to highly electronegative elements such as $\mathrm{F}$ ). For the " 1 st discharge" sample, the shoulder at the lower binding energies reveals the presence of $\mathrm{Li}_{2} \mathrm{O}_{2}$ after 1 discharge, which is in agreement with the in situ XRPD results. The relative contribution of $\mathrm{Li}_{2} \mathrm{O}_{2}$ peak to the $\mathrm{O} 1 \mathrm{~s}$ spectra decreases from $14 \%$ to $4 \%$ from the $1^{\text {st }}$ to the $2^{\text {nd }}$ discharge samples. This implies that less $\mathrm{Li}_{2} \mathrm{O}_{2}$ formed on the $2^{\text {nd }}$ discharge sample. The $\mathrm{O} 1$ s spectrum of " 2 nd discharge" sample also shows increased contributions from single- and double-bonded oxygen to carbon indicating increased side products formed by decomposition of the electrolyte. The $\mathrm{C} 1$ spectra of the discharge samples (see Figure S11) confirm increased contribution from decomposition products when discharging the electrodes for the $2^{\text {nd }}$ time. 


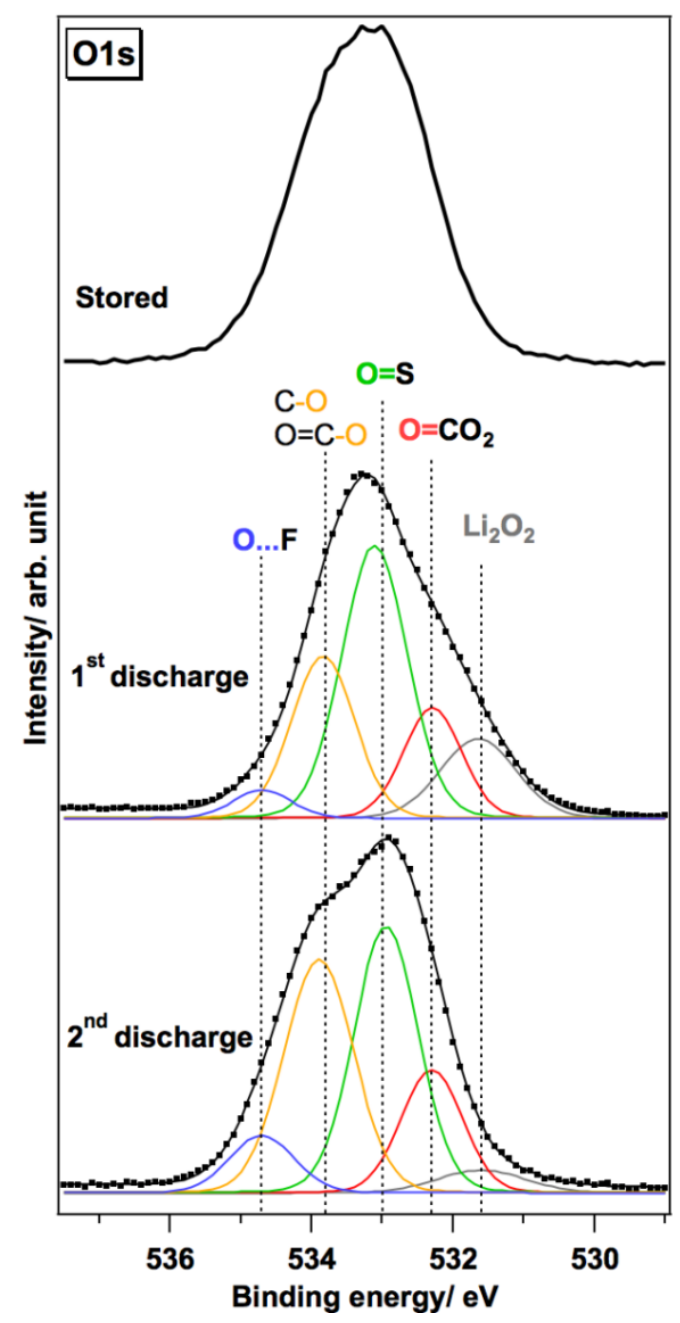

Figure 9: O1s spectra of ex situ analyzed cathodes after 1 or 2 discharge together with stored cathode.

The XPS result, which is disclosing smaller amount of $\mathrm{Li}_{2} \mathrm{O}_{2}$ while higher amount of side products on the $2^{\text {nd }}$ discharge sample compared to the $1^{\text {st }}$ discharge sample, could explain the low intensity of the diffraction peaks of $\mathrm{Li}_{2} \mathrm{O}_{2}$ observed for the in situ XRPD of the $2^{\text {nd }}$ discharge/charge for battery 3 .

\section{Experimental}

Battery assembly: Figure 1 shows The $\mathrm{Li}-\mathrm{O}_{2}$ capillary cell design. The cathode was made by dipcoating hollow stainless steel (SS) wires (outer diameter $0.3 \mathrm{~mm}$ ), in a slurry of Super C65 (carbon black from TIMCAL Graphite and Carbon) and $20 \mathrm{wt} \%$ polyvinylidene fluoride (PVDF) in N-methyl2-pyrrolidome (NMP) for in situ studies and 15-20 wt\% PVDF for ex situ studies. The slurry used for 
the cathode in battery 3 contained trace amount of diamond powder to facilitate easy alignment of the battery in the X-ray beam. The small carbon cathode was coated at the end of the SS-wire (which had been slightly sanded and cleaned in acetone before use) by dipping the SS-wire in the slurry and drying the slurry with a heating gun at $100-110{ }^{\circ} \mathrm{C}$. This process was repeated until a cathode of a sufficient size was made. The cathode stick was dried in vacuum oven inside a glovebox at $80^{\circ} \mathrm{C}$ for $12 \mathrm{~h}$. The carbon cathodes for the in situ study had an average weight of $0.2 \mathrm{mg}$ and the cathodes for the studies of batteries without X-ray and the cathodes for the XPS analysis had an average weight between 0.1$0.2 \mathrm{mg}$. The Li-anode was prepared by smearing Li onto a $0.4 \mathrm{~mm} \mathrm{SS}$-wire which then was glued into a capillary using two-component epoxy. Borosilicate capillaries with an outer diameter of $1.05 \mathrm{~mm}$ were used for the ex situ XRPD tests, whereas $1 \mathrm{~mm}$ quartz capillaries were used for in situ XRPD measurements. The quartz capillaries were prepared with a Li-anode in one end and a piece of borosilicate capillary $\left(1.05 \mathrm{~mm}\right.$ diameter) in the other end in order to attach it easily to the $\mathrm{Li}-\mathrm{O}_{2}$ flushing unit. The flushing unit had two valves with a quick connector in one end for the inlet of oxygen. The carbon cathode was attached to the unit with a Teflon ferrule and the capillary was filled with 1M LiTSFI in DME electrolyte and attached to the unit with a Teflon ferrule. Both the anode and cathode were covered by the electrolyte. The two Teflon ferrules hinder short circuiting the battery. The Li- $\mathrm{O}_{2}$ capillary batteries were assembled inside a glovebox and were tightly sealed before removal from the glovebox. The batteries were flushed several times with oxygen gas (grade 5.0) which resulted in an overpressure of approximately 1.5-2 bars inside the batteries. The valves ensured that the capillary unit could be moved around with the flushing unit working as an oxygen reservoir. The airexposed end of the capillary coated SS-wire was carefully sealed with two component epoxy glue before the oxygen activation process. Small additional wires were attached to the anode and cathode side of the battery for attaching the potentiostat to the in situ setup.

Battery tests: Several capillary-based batteries were electrochemically tested using a Biologic potentiostat and EC-lab software. To analyze formation and decomposition of $\mathrm{Li}_{2} \mathrm{O}_{2}$ in $\mathrm{Li}-\mathrm{O}_{2}$ cells, three different cells were used in the in situ synchrotron-based XRPD experiments. The batteries for $e x$ situ XRPD and XPS analysis were left after oxygen filling for 2- $3 \mathrm{~h}$. at OCV before being discharge/charged at $-/+3 \mu \mathrm{A}$ to $2 \mathrm{~V} / 4.6 \mathrm{~V}$. The in situ battery 1 was activated for approx. $5 \mathrm{~h}$., followed by a discharge at $-3 \mu \mathrm{A}$ for $18 \mathrm{~h} 48 \mathrm{~min}$, a discharge at - $4 \mu \mathrm{A}$ for $3 \mathrm{~h}$. $45 \mathrm{~min}$, and a final discharge at $-6 \mu \mathrm{A}$. The battery was charged at $5 \mu \mathrm{A}$ and discharged for a second time at $4 \mu \mathrm{A}$ for $1 \mathrm{~h}$, 
before being recharged at $4 \mu \mathrm{A}$ (as seen in Figure 2). The XRPD patterns of the cathode were collected every $10 \mathrm{~min}$ with an exposure time of $30 \mathrm{~s}$. The voltage of the first discharge at $3 \mu \mathrm{A}$ have been smoothed using Origin Pro 8.6, using the Adjacent-Avarage signal process. The second discharge of battery 1 was short, $1 \mathrm{~h}$, and no changes in the area of the diffraction peaks or FWHM were observed probably due to the short duration of the discharge, and the data is not presented in this paper.

After $3 \mathrm{~h}$ of resting time at OCV battery 2 was discharged without being exposed to X-ray radiation at $5 \mu \mathrm{A}$ to $2 \mathrm{~V}$. It was then charged in situ with XRPD measurements every $10 \mathrm{~min}$ and $30 \mathrm{~s}$ exposure time, at $5 \mu \mathrm{A}$ for $100 \mathrm{~min}$ and at $4 \mu \mathrm{A}$ for $110 \mathrm{~min}$. The battery was charged at $4 \mu \mathrm{A}$ with continuous exposure to X-ray for approximately $6.6 \mathrm{~h}$. Similar to battery 1 , battery 2 gave a noisy battery test curve, which was restarted three times due to voltage spikes.

Battery 3 was kept at OCV for 3 h before battery discharge and charge without X-ray exposure at $4 \mu \mathrm{A}$. The $2^{\text {nd }}$ discharge-charge was performed in situ with XRPD patterns being collected every 10 min with an exposure time of $60 \mathrm{~s}$. The battery was discharged at $-5 \mu \mathrm{A}$ for $100 \mathrm{~min}$ followed by a discharge and charge at $-/+6 \mu \mathrm{A}$.

XRPD: Beamline I711 at MAX-lab was used for the XRPD measurements for battery 1 and 2 with a wavelength of $0.9940 \AA$, a detector distance of approximately $96 \mathrm{~mm}$ and a slit size of $0.2 * 0.2$ for the batteries. Between the XRPD measurements the shutter was closed in order to minimize any radiationinduced degradation of the sample. The data were integrated by Fit2D ${ }^{24}$, normalized to the background and fitted in Topas $3^{25}$ as single pseudo-Voigt peaks and a background described by a $5^{\text {th }}$ order Chesbyschev function. Battery 3 was measured at the ESRF at the Swiss Norwegian beamline with a wavelength of $0.7735 \AA$, a distance to the detector of approximately $194 \mathrm{~mm}$ and a slit size of 0.15*0.15. Ex situ XRPD was measured with a BrukerD8 using CuK $\alpha$ radiation.

XPS: Before ex situ analysis by XPS, the capillary batteries discharged one and two times, respectively were carefully disassembled in the glovebox, and the cathodes were washed with dried DME and left for drying. A background sample was stored in electrolyte overnight inside the glovebox before being washed and sealed under similar conditions as the discharged cathodes. The XPS samples were prepared in glovebox on $\mathrm{Cu}$-tape and transported to the XPS machine inside an airtight transfer chamber. XPS measurements were performed on a commercial in-house PHI 5500 spectrometer with monochromatic $\mathrm{Al} \mathrm{K \alpha}$ radiation. Scans were made with a step size of $0.1 \mathrm{eV}$ and 35 to 50 repeated cycles. Igor Pro ${ }^{26}$ was used for spectral analysis. 


\section{Conclusion}

The in situ XRPD analysis of the cathodes of $\mathrm{Li}-\mathrm{O}_{2}$ capillary batteries revealed precipitation of $\mathrm{Li}_{2} \mathrm{O}_{2}$ by the growth of the $100,101,102$ and 110 diffraction peaks upon discharge. Only the $\mathrm{Li}_{2} \mathrm{O}_{2}$ diffraction peaks were affected by the discharge/charge of the in situ analyzed batteries. The development in the FWHM indicated growth in the crystallite size, as seen by narrowing of the 100 and 101 diffraction peaks upon discharge. A constant exposure to X-ray during charge, increased the decomposition rate of the 100 and 101 diffraction peaks remarkable, compared to a small increase for the 110 diffraction peak. The development of the FWHM upon constant X-ray exposure was dramatically and could indicate that $\mathrm{X}$-ray exposure affects the general $\mathrm{Li}_{2} \mathrm{O}_{2}$ decomposition. Upon charging of the battery a complete decomposition of $\mathrm{Li}_{2} \mathrm{O}_{2}$ was observed. The $2^{\text {nd }}$ discharge/charge showed a single very low intensity $\mathrm{Li}_{2} \mathrm{O}_{2}$ diffraction peak which together with the XPS results indicated a decrease in $\mathrm{Li}_{2} \mathrm{O}_{2}$ precipitation upon deep discharged cycling.

\section{Acknowledgement}

The authors acknowledge support from University of Uppsala, Department of Chemistry - Ångström Laboratory, Structural Chemistry, Prof. Kristina Edström and the MAX-lab staff at beam-line I711. Further acknowledgement is given to the ESRF staff at the Swiss-Norwegian beam-line, the ReLiable project funded by the Danish Council for Strategic Research-Programme Commission on Sustainable Energy and Environment (project no. 11-116792), and The Danish Research Council for the financial support of synchrotron measurements (DANSCAT).

\section{References}

1. G. Girishkumar, B. McCloskey, A. C. Luntz, S. Swanson and W. Wilcke, J. Phys. Chem. Lett., 2010, 1, 2193-2203.

2. J. Xiao, D. Mei, X. Li, W. Xu, D. Wang, G. L. Graff, W. D. Bennett, Z. Nie, L. V. Saraf, I. A. Aksay, J. Liu and J.-G. Zhang, Nano Lett. , 2011, 11, 5071-5078.

3. Y. Li, J. Wang, X. Li, D. Geng, R. Li and X. Sun, Chem. Commun., 2011, 47, 9438-9440.

4. M. M. Storm, M. Overgaard, R. Younesi, N. E. A. Reeler, T. Vosch, U. G. Nielsen, K. Edström and P. Norby, Carbon, 2014, submitted. 
5. B. D. McCloskey, D. S. Bethune, R. M. Shelby, T. Mori, R. Scheffler, A. Speidel, M. Sherwood and A. C. Luntz, J. Phys. Chem. Lett., 2012, 3, 3043-3047.

6. M. M. Ottakam Thotiyl, S. A. Freunberger, Z. Peng and P. G. Bruce, J. Am. Chem. Soc., 2013, 135, 494500.

7. M. Balaish, A. Kraytsberg and Y. Ein-Eli, Phys. Chem. Chem. Phys., 2014, 16, 2801-2822.

8. R. Younesi, P. Norby and T. Vegge, ECS Electrochem. Lett. , 2014, 3, A15-A18.

9. R. Younesi, University of Uppsala Ph.D. thesis, 2012, Characterization of Reaction Products in the Li-O2 Battery Using Photoelectron Spectroscopy.

10. J. Shui, F. Du, C. Xue, Q. Li and L. Dai, ACS Nano, 2014, 8, 3015-3022.

11. J. S. Hummelshøj, J. Blomqvist, S. Datta, T. Vegge, J. Rossmeisl, K. S. Thygesen, A. C. Luntz, K. W. Jacobsen and J. K. Nørskov, J. Chem. Phys, 2010, 132, 071101.

12. H. Lim, E. Yilmaz and H. R. Byon, J. Phys. Chem. Lett., 2012, 3, 3210-3215.

13. K. R. Ryan, L. Trahey, J. S. Okasinski, A. K. Burrell and B. J. Ingram, J. Mater. Chem. A, 2013, 1, 69156919.

14. J.-L. Shui, J. S. Okasinski, P. Kenesei, H. A. Dobbs, D. Zhao, J. D. Almer and D.-J. Liu, Nat Commun, 2013, 4.

15. R. E. Johnsen and P. Norby, J. Appl. Crystallogr., 2013, 46, 1537-1543.

16. Y. S. Mekonnen, K. B. Knudsen, J. S. G. Mýrdal, R. Younesi, J. Højberg, J. Hjelm, P. Norby and T. Vegge, J. Chem. Phys, 2014, 140, --

17. M. M. O. Thotiyl, S. A. Freunberger, Z. Q. Peng and P. G. Bruce, J. Am. Chem. Soc., 2013, 135, 494-500.

18. B. D. McCloskey, D. S. Bethune, R. M. Shelby, G. Girishkumar and A. C. Luntz, J. Phys. Chem. Lett., 2011, 2, 1161-1166.

19. J. Liu, M. Roberts, R. Younesi, M. Dahbi, K. Edström, T. Gustafsson and J. Zhu, J. Phys. Chem. Lett., 2013, 4, 4045-4050.

20. R. Younesi, M. Hahlin, M. Roberts and K. Edström, J. Power Sources, 2013, 225, 40-45.

21. R. Younesi, M. Hahlin, F. Björefors, P. Johansson and K. Edström, Chem. Mater., 2012, 25, 77-84.

22. Y.-C. Lu, A. N. Mansour, N. Yabuuchi and Y. Shao-Horn, Chem. Mater., 2009, 21, 4408-4424.

23. S. Leroy, H. Martinez, R. Dedryvère, D. Lemordant and D. Gonbeau, Appl. Surf. Sci., 2007, 253, 48954905.

24. A. P. Hammersley, ESRF Internal Report 1997, ESRF97HA02T.

25. Topas3, BRUKER-AXS, 2000. 
26. IGORPro, WaveMetric, Version 4.0 